\title{
THE POSITION OF PUBLIC ENFORCEMENT OFFICERS WITH REFERENCE TO ENFORCEMENT ON AGRICULTURAL LAND
}

\author{
Mirela Smiljanić Ličina ${ }^{1}$, Darko Golić2 \\ *Corresponding author E-mail: mirelasmiljanic.izvrsitelj@gmail.com
}

\begin{abstract}
A R T I C LE I N F O
A B S T R A C T

Review Article

Received: 11 July 2020

The subject of this paper is the analysis of the legal

Accepted: 15 August 2020 nature of public enforcement officers as holders of public authority, their place in the judicial system of the Republic doi:10.5937/ekoPolj2003011S

UDC 347.964.3:332.7

Keywords:

public enforcement officers, legal nature, public authority, agricultural land, supervision of Serbia with special reference to enforcement on agricultural land owned by the enforcement debtor and the process of supervision and control of public enforcement officers. Fast and efficient collection of creditors' claims is one of the basic tasks of the enforcement procedure and as such, it is a precondition for the efficient functioning of the judicial system. In the Republic of Serbia, these goals are ensured by the introduction of first (private) enforcement officers, and afterward, public enforcement officers as JEL: K20, K25, K42, K100 a new judicial profession, to which some of the public authorities have been delegated, i.e. authorities that only courts once had.
\end{abstract}

(C) 2020 EA. All rights reserved.

\section{Introduction}

The most important part of the whole, of any legal order, is the system of protection of subjective rights. On the other hand, the enforcement procedure also aims to maintain the legal order. The broadest observed principle of constitutionality and legality cannot be separated from the respect and realization of the subjective rights of all subjects in the legal system. Such a request is an imperative and the ultimate goal of the principles of constitutionality and legality (Šarkić, 2016).

Enforcement proceedings are a legally prescribed way of enforcing or securing a creditor's claim, through a court as a state authority as well as through a public

1 Mirela Smiljanić Ličina, Public Enforcement Officer for the area of the Higher and Commercial Court in Novi Sad, Maksima Gorkog no. 13, 21000 Novi Sad, Serbia, Phone: +38160070 26 00, E-mail: mirelasmiljanic.izvrsitelj@gmail.com, ORCID ID (https:// orcid.org/0000-0002-8894-481X)

2 Darko Golić, Ph.D., Associate Professor, The Faculty of Law for Commerce and Judiciary in Novi Sad, University Business Academy of Novi Sad, Geri Karolja no. 1, 21000 Novi Sad, Serbia, Phone: +381693312633, E-mail: g.darko83@gmail.com, ORCID ID (https:// orcid.org/0000-0003-2315-5040) 
enforcement officer as a holder of an executive human rights function. The basic meaning of the enforcement procedure is realized in the efficient settlement of the claims of the enforcement creditor, which is determined by an enforceable or credible document. The enforcement procedure completes the system of providing legal protection (Lazarević, 2014) that is the right to legal protection ends only with the successful completion of the enforcement procedure. If there were no efficient enforcement system litigation would not have the legal meaning, given that the creditor would obtain an enforceable document that would not be collectible, and the meaning of such litigation would be questionable. The enforcement document, as a rule, represents the legal basis for determining and conducting the enforcement procedure. The enforceable document, more precisely the claim of the enforcement creditor contained in it, is the essence due to which the enforcement procedure is conducted (Ličina Smiljanić, 2018).

The most important authority delegated to the public enforcement officers is the enforcement on the entire property of the enforcement debtor, which certainly includes the enforcement on the agricultural land owned by the enforcement debtor. This matter, although it is in the Law on Enforcement and Security Interest ("Official Herald of RS", no. 106/2015, 106/2016 - authentic interpretation, 113/2017 - authentic interpretation and 54/2019 - hereinafter: Law on Enforcement and Security Interest, current law, LESI) is insufficiently processed, given the frequency of this method of enforcement in the Republic of Serbia and thus and its significance in enforcement proceedings.

\section{Methodology}

In addition to general scientific methods, special methods have been applied in the paper for a more comprehensive study of the specifics of the position of public enforcement officers in the legal system of Serbia and analysis of the powers prescribed by law that have been delegated to them. That primarily refers to historical law, theoretical law, and normative, legal-dogmatic, and sociological methods of understanding the law. The historical-legal method will be used to study the development of the institute itself and the need for return and to introduce public enforcement officers into the legal system of the Republic of Serbia. The normative method will be used during the legal analysis of normative solutions within our legal system, but also international legal standards, and the practice of domestic and international courts and other relevant institutions. Dogmatic method of observation of specific legal provisions will indicate possible and necessary improvements to make certain legal solutions in our legal system "better". Sociological interpretation of the institute of public enforcement officers will give an account of their significance in society and justification of the need for the development of enforcement in Serbia. Starting from the basic principles of theoretical legal method, consulted and presented are the authors who have dealt with this and related issues such as issues of enforcement, public authority, control of the work of public enforcement officers, notaries, etc. 


\section{Reasons for returning private enforcing officers to the judicial system of the Republic of Serbia}

Alignment of national legislation with Chapters 23 and 24 of the EU acquis is one of the highest priorities of the RS Government, as stated in its key strategic document for judicial reform, the National Strategy for Judicial Reform (hereinafter: NSRP) for the period from 2013 to 2018, for which the Government of the RS on 31 July 2013, at the proposal of the Ministry of Justice, adopted an Action Plan for its implementation. The need to establish a more efficient and sustainable enforcement system has resulted from many judgments by the European Court of Human Rights (hereinafter text: ECHR) against Serbia, given that most of them referred to the shortcomings of the enforcement system, which as such was regulated by the laws on enforcement proceedings of 1978, 2000 and 2004, i.e. in the period when the courts and court enforcement officers were competent to enforcement procedures.

The Yugoslav Law on Enforcement Procedure from 1978 was the legal basis for enforcement in the countries that were once part of the SFRY. The main reasons for nonenforcement, until 2011, were complex procedures, excessive formalism, procedural repetition, an abundance of legal remedies, the privileged position of the state, lack of interest in the field of enforcement, etc. All this has led to an increasing backlog of enforcement cases and an overburden of judges, which has led the RS government to decide to drastically change the enforcement system and introduce a system that has already proved successful in other countries: private enforcement officers. The National Assembly of the Republic of Serbia adopted the Law on Enforcement and Security Interest in 2011, which introduced private (self-employed) enforcement officers. However, the Law on Enforcement and Security Interest from 2011 failed to solve all the shortcomings of the enforcement procedure, so in 2015 a new Law on Enforcement and Security Interest was passed, the implementation of which began in 2016. It introduces - public enforcement officers. The legislator, therefore, decided to give the public enforcement officers significant public powers. The public enforcement officers also received a part of the judicial power, such as making a writ of execution based on a credible document to settle a monetary claim arising from communal services and related activities, and he can even take some repressive measures either with the assistance of state bodies. Amendments to the Law on Enforcement and Security Interest from 2019 (hereinafter LESI), which began to be applied on 1 January 2020, the public enforcement officer was given even broader powers (more on this below).

\section{Position of public enforcement officers and public authorities}

The Constitution of Serbia enables certain public authorities to be entrusted by law to companies, institutions, organizations, and individuals (Pajvančić, 2009). Given that the entrusting is regulated by the same article that regulates the entrustment of affairs to local self-government units and autonomous provinces, then the entrustment should be guided by the same criteria, which is defined by the Constitution so that it 
is performed "in the interest of more efficient and rational realization of rights and obligations meeting their needs of immediate interest for life and work." However, this is only a guideline for legislative policy, and the formal restriction refers to the possibility of entrusting only certain public powers, and not the whole business, that is, the competencies of the state. In this respect, public enforcement officers become holders of public authority in the function of judicial activity.

LESI defines a public enforcement officer as an enforcer of public authorities entrusted to him by (this or another) law, who performs activities as an entrepreneur or as a member of a partnership whose members are exclusively public enforcement officers. The public enforcement officer is therefore a private judicial profession with entrusted public authority. A public enforcement officer is an individual appointed by the Minister of Justice. He has a status of an official, conducts the enforcement within the limits of the writ of execution, and performs other authorities entrusted to him by the Law. The public enforcement officer must meet conditions prescribed by Law for his appointment. Public enforcement officers act as holders of public authority who perform their activities independently and on their own. Independence is not a determinant of legal status, but more of a guaranteed absence of influence on work and conduct. It is realized in relation to state bodies, and also concerning parties where the state still regulates public enforcement officer activities by legal rules, in a way that controls and supervises the work of public enforcement officers.

The principles of public and private law are mixed in the activities of the public enforcement officer. Although he represents a private profession, he is the bearer of public authority, which gives him a special character and determines his mixed nature. The public enforcement officer is obliged to really and constantly deal with public enforcement and to exercise the entrusted powers responsibly and with dignity, using all available material and human resources (Đurđević, 2014). ${ }^{3} \quad$ Per the principle of formality, the public enforcement officer is obligated to act by the law and under the rules prescribed by the law. The full application of the principle of formality is reflected in the fact that the public enforcement officer cannot refuse to perform a certain action, i.e. he cannot be released from the obligation to act in the process. The possibility of refusing to take certain actions is exclusively prescribed in situations provided by the law, and this is mainly when the public enforcement officer must observe the principle of proportionality. The public enforcement officer, therefore, must carry out the procedure once to the end, just as the court has such an obligation. On the other hand, in those legal situations in which the competitive jurisdiction of public enforcement officers is prescribed - the principle of disposition dominates, which is certainly one of the basic principles of the

3 Speaking about the goals of notarial activity, Đurđević states that it should fulfill three important legal-political tasks: 1) to contribute to the full realization of the purpose of form in modern civil law; 2) to relieve the courts and administrative bodies and 3) to facilitate access to justice for legal entities. 
executive law. It characterizes the enforcement procedure in its basic determination. As a rule, the holder of an enforceable document has the right to dispose of his right. Whether he will request enforcement or not is in his exclusive competence (Šarkić, 2016).

The public enforcement officer is obligated to apply the law objectively because his position is not the position of the party's commissioner or judge in party disputes. The principle of impartiality is an inseparable part, in a broader sense, of the principle objectivity - primarily because the initial premise of the principle is the duty of the public enforcement officer to provide and offer equal treatment to the parties in the enforcement procedure, even though the general concept of LESI is such that the enforcement creditor comes to the fore. From that point of view, the principle of protection of the enforcement debtor is a global principle in which the enforcement debtor is protected so that no action against him can be carried out contrary to the law. The principle of protection of the enforcement debtor in the broadest sense implies the ability of the enforcement debtor to challenge the allegations of the enforcement creditor, to contest for the most appropriate means of enforcement, to reduce the harmful consequences of enforcement and otherwise protect his interests (Šarkic, 2016) with, on the other hand, the application of the principles and efficiency which implies rapid protection of the rights of the parties in the procedure, especially the enforcement creditor. However, as stated above, the principle of efficiency must not be to the detriment of the rights of the enforcement debtor or third parties, but above all must provide rapid and effective protection.

For the sake of more efficient and rational realization of the rights and obligations of citizens, the state sometimes in a special legal procedure, prescribed by the Constitution, renounces exclusivity to exercise certain prerogatives, its powers to act for public interests (hence the term public powers) and entrusts them to others entities, whereby these entities (only in the exercise of these powers) have the same rights and obligations as state administrative bodies (Art. 51 par. 1 of the Law on State Administration), but retaining responsibility for their timely and proper enforcement. Thus, it does not waive its right to exercise public authority. It does not transfer them to other subjects, but in some cases, entrusts them to perform, which still keeps them for itself (Milkov, 2009). ${ }^{4}$ These are those entities for which the state has assessed that certain jobs have such a social significance (general interest) that requires efficiency and quality to improve their actions or to make the realization of their rights necessary for the citizens, for the realization of which it is necessary to exercise public authority, more efficiently.

4 Speaking about the nature of public authorizations, Milkov states: "The decision on which subjects will be 'entrusted' with the exercise of public authorizations is not free. It does not depend on the discretion of the legislator, but is conditioned by the nature of the activity..." According to him, these are vital, not derived interests, and the performance of those activities must be continuous, uninterrupted and equally accessible to everyone. 
By public authorizations, therefore, we imply one of the forms of exercising power, i.e. one of the functions of the authority. Public authorization differs from state legal functions by the entities entrusted with this function, as well as by the grounds on which the authorization to perform this function arises.

Having in mind the section of Art. 51 of the Law on State Administration, which sanctions that holders of public authority in performing entrusted tasks of state administration have the same duties as state administration bodies, it follows that in the part where they exercise public authority, holders of public authority for timely and proper performance, based on provision Art. 136 st. 1 of the Constitution, are held accountable by the Government (Tomić, 2016). However, as the Government even after entrusting public authorities retains responsibility for their implementation, through the ministry responsible for the subject area, e.g. it supervises the proper work, directs them, issues instructions, etc. The question arises whether in that way the executive power seizes the jurisdiction of the judiciary, that in the part of the authority regarding the supervision of the work of public enforcement officers, where it discusses and resolves issues motioned by legal remedies, on which the competent court also decides on.

Given the above, the question of justification for entrusting public authorities to entities outside the system of regular authorities can also be raised. As a result of the great need to establish a more efficient and sustainable enforcement system in the Republic of Serbia, inter alia, and due to numerous judgments of the European Court of Human Rights in the field of non-enforcement of court decisions, issued due to lengthy enforcement proceedings (see case Ilic against Serbia), a backlog of enforcement cases in the courts (see case Samardzic and AD Plastika v. Serbia), excessive remedies (see subject Bulovic v. Serbia), etc. ${ }^{5}$, and the fact that the ECHR has found in various cases that the State is responsible for the proper functioning of the enforcement system (see EVT v. Serbia), the Government of the Republic of Serbia has decided to drastically change the enforcement system. The Government assessment was that it is justified, at the point of view on realizing human rights more rationally and purposefully, to entrust part of the public authority to entities outside the system of classical government (Markovic, 2015). On the other hand, the legislator entrusted the enforcer with the performance of part within the judicial function in a broader sense, which raises the question of the existence of a constitutional basis for such a decision (Andrei et al., 2017). According to the part of a procedural theory, the enforcement procedure has no technical character, because in this procedure it is decided on the subjective right to enforcement of a decision in which the existence of claims is established authoritatively and undoubtedly, and if the preconditions for enforcement are met the application of direct and indirect coercion is determined. Enforcement officers,

5 Author's note: Cases against State of Serbia in the area of non-enforcement of court decisions in which the ECHR issued a final decision are mainly based on the $2000 \mathrm{ZIO}$ and the $2004 \mathrm{ZIO}$. It should be noted that in Art. 304 of the 2004 ZIP stipulated that all enforcement proceedings initiated before 23 February 2005 should be completed in accordance with the previous law. 
although representatives of the new judicial profession, who are entrusted with the exercise of judicial power in enforcement matters, are not courts already established by law (Zoroska-Kamilovska, 2015).

In practice, the question arose as to whether the extension of the powers of the enforcers would be following Art. 32 par. 1 of the Constitution of the Republic of Serbia and Art. 6 ECHR. In this regard, the Constitutional Court of Serbia considered the competence of the enforcement officer to determine enforcement and in its decision on the subject of IUz no. 782/12 adopted on 27 February 2014 and concluded that the constitutional guarantees under Art. 32 st. 1 of the Constitution of the Republic of Serbia, which guarantees everyone the right to have their rights and obligations decided by an independent, impartial, and legally established court, cannot be interpreted as mandatory at all stages of the proceedings. This opinion is in line with the case-law of the ECHR, according to which states do not have to ensure that a judicial body decides at every stage on any dispute concerning rights and obligations - if one stage of the proceedings is conducted before another body; the requirements of this provision are met if the dispute is decided at a later stage by a court that has full jurisdiction and decides on it.

\section{Enforcement officers as a new judicial profession}

The very notion of judicial activity, in the organizational sense, is broader than the notion of judicial power, because in addition to the court as holders of judicial activity, therefore, prosecutors, attorneys and other judicial professionals (...), social bodies and individuals who have a role of judicial or para-judicial body (...) (Rakić-Vodinelić, 2012), are included, therefore public enforcement officers also. In functional terms, judicial activity, unlike the judiciary, does not consist only in the pronouncement of judgments (judicates) - it includes the organization of the judiciary and the organization of judicial activity; i.e. resolving the issue of jurisdiction (...). The most significant difference is reflected in the fact that only courts exercise power and only through the pronouncement and enforcement of court decisions that power exists, while other bodies of judicial activity help the court to exercise power as the legal order dictates (Rakić-Vodinelić, 2012), with certain entrustments of the exercise of certain elements and segments of the judiciary to other bodies or entities. This entrustment is regulated by law, based on constitutional authority.

The general characteristic of all judicial professions is that they must meet certain criteria arising from the basic content of the judicial system. It is, above all, strict abidance of international legal standards, the Constitution, laws, bylaws, and other rules of the judicial profession. All practitioners of the judicial profession must be very sensitive to the ethical rules that apply in general to all judicial professions or each of the judicial professions individually. It is certainly important for all of them that they serve the fulfillment and protection of the basic goals guaranteed and proclaimed by the Constitution and the law, including their property (Nikolic et al., 2012). 


\section{Structure of enforcement procedure with reference to the enforcement procedure on agricultural land and enforcement supervision mechanisms}

Public enforcement officers have standard authorities, but their application is determined by certain specifics concerning the procedure itself, which prescribes certain restrictions, but also the specifics of the procedure.

According to the valid law, the enforcement procedure is divided into two parts: the enforcement procedure and the security interest procedure. According to the Serbian model, enforcement, as a rule, is determined by the court and only exceptionally by the public enforcement officer in the case of settling the monetary claim of the enforcement creditor arising from utility services and related activities and when it comes to settling the monetary claim against the enforcement debtor from Art. 300 par. 2-4 of LESI (so-called budget cases). The stage of enforcement occurs when a writ of execution is made. In the enforcement procedure, enforcement is carried out to realize the claims from the executive or credible document, which means that if there are no claims, enforcement cannot be requested (Lazarević, 2014).

Enforcement documents that are enforced by the application of the Law on Enforcement and Security Interest most often originate from the procedure before the court or, if they are a monetary claim, from the procedure before the administrative body and represent acts of state bodies. However, in the last ten years, enforcement documents have become more frequent, which are not created in proceedings before state bodies, but before parastate bodies, holders of public authority, the will of the parties, or an act of private law entities. They are regulated by special laws, such as, for example, the Labor Law, the Law on Protection of the Right to Trial within a Reasonable Time, the Law on Peaceful Settlement of Disputes, the Law on Mortgage, the Law on Financial Leasing, etc. The reason for the creation of such enforcement documents is the desire to speed up the path from the occurrence of a legal obligation to its enforcement and avoid litigation, which is claimed to take a long time and is slow-paced (Ličina Smiljanić, 2018).

By analyzing the current model of enforcement, we conclude that with the introduction of public enforcement officers, the entire structure of the enforcement procedure has largely passed from the court's jurisdiction to the jurisdiction of public enforcement officers.

Thus, the public enforcement officer is also authorized for conducting enforcement on agricultural land, by entering the writ of execution annotation in the real estate cadaster, assessing the value of agricultural land, selling and settling the enforcement creditor from the sale price. During the enforcement, the public enforcement officer is obliged to take into account the proportion between the amount of the enforcement creditor's claim and the value of the agricultural land on which the enforcement is determined. The subject of enforcement may not be agricultural land of a farmer with an area of up to 10 acres, except when settling a monetary claim secured by a contractual mortgage or pledge statement (Art. 164 LESI). This means that the enforcement must be carried out on the real estate, agricultural land, and for there to be the status of a farmer of the owner. The law in Art. 164 and Art. 2 did not precisely define the term farmer, and it 
remains insufficiently precise whether the term farmer refers only to a person who has a registered agricultural household or it can also be a person-farmer who lives exclusively or predominantly from agricultural activities. Law on Agriculture and Rural Development ("Official Herald of RS", No. 41/2009, 10/2013 - dr. Law and 101/2016 - hereinafter: the Law on Agriculture and Rural Development) in Art. 2 par. 1 pt. 4 defines an agricultural holding as a production unit on which a business company, agricultural cooperative, institution, or other legal entity, entrepreneur, or farmer performs agricultural production. In par. 8 of the same article, the law defines a farmer as a person who is the holder or member of a family farm that is exclusively engaged in agricultural production and par. 10 defines that agricultural land includes fields, gardens, orchards, vineyards, meadows, pastures, fishponds, reeds and swamps, as well as other lands (sinkholes, abandoned riverbeds, a land overgrown with low shrubs, etc.), which by their natural and economic conditions can be rationally used for agricultural production. From the above, it would be logical for the public enforcement officer, and given that there is room for him to decide for himself whether it is agricultural land or not, and whether it is a farmer, apply the provisions of Art. 2 of the Law on Agriculture and Rural Development.

Therefore, during the enforcement, the farmer must be left with a minimum area of 10 acres, except in the case when the owner of the plot - the farmer - has encumbered this plot with a contractual mortgage or a pledge statement. In this case, the minimum amount of land will not be determined for the enforcement debtor, since the subject of the mortgage can be immovable property, and thus the right of ownership on the land.

The public enforcement officer determines the value of agricultural land with a conclusion, most often by hiring a certified appraiser of the appropriate profession to assess the market price of agricultural land, to which the parties have no right to object, but may challenge the assessment (both height and other elements) in a request for rectification of irregularities. Under the provisions of Article 271 par. 2 of the Law on Civil Procedure ("Official Herald of RS", No. 72/2011, 49/2013 - decision of Constitutional Court 74/2013 - decision of CC, 55/2014, 87/2018 and 18/2020 hereinafter: LCP), a party may hire an expert or other expert registered in the register of court experts, who will make objections to the submitted finding and opinion, or a new finding and opinion in writing. The public enforcement officer will try to coordinate the given findings and opinions, and if he fails to coordinate them, e.g. if he considers that the important facts have not been sufficiently discussed, he will entrust another expert witness to give findings and opinions and inform the parties (Art. 271 par. 3 and 4 of the LCP). The assessment of the value of agricultural land must not significantly deviate from the market price on the day of assessment. The value certainly depends on whether there are certain encumbrances on it, i.e. rights on the property that will remain after the sale. If such rights exist, the value of the real estate will certainly be lower. After the assessment and the conclusion on the determination of real estate, the public enforcement officer schedules the sale with a conclusion, and when the agricultural land is sold ex officio, he approaches the settlement of the enforcement creditor and 
other persons who aspire to be settled. If the sale is made by public auction, at the first public auction the agricultural land cannot be sold below $70 \%$ of the estimated value (initial price), and at the second public auction, it cannot be sold below 50\% of the estimated value. If the agricultural land is sold through a direct agreement, the enforcement creditor is considered settled in the amount of the achieved price, but if it is lower than $30 \%$ of the estimated value, it is considered settled in the amount of $30 \%$ of the estimated value of the real estate or agricultural land. If the agricultural land is not registered in the real estate cadaster, the enforcement creditor must submit documents, along with the enforcement motion, that would make it suitable for registering the ownership on the agricultural land in favor of the enforcement debtor. The court is obliged to immediately forward the submitted document to the body that maintains the real estate cadaster and to stop the procedure until the registration of the property ownership to the enforcement debtor is complete. If the motion for enforcement indicates agricultural land or its part that is not registered in the real estate cadaster and on which ownership cannot be registered, the enforcement creditor must state that registration of the property is not possible and attaches it to the motion for enforcement. In that case, the court issues a writ on execution on agricultural land that is in the unregistered ownership of the enforcement debtor, provided that the enforcement creditor submits or appoints, as proof of unregistered ownership, one of the documents determining the unregistered ownership of the enforcement debtor.

\section{Chamber of Public Enforcement Officers and Supervision Mechanisms}

In regards to the supervision of enforcing proceedings, there are certain international standards. In Recommendation No. 17 (2003) par. IV4. it is prescribed that "The enforcement officer should perform his duties honorably and professionally, and always act per recognized high professional and ethical standards. In their treatment of the parties to the proceedings, they should be impartial and subject to professional monitoring and supervision (...)", and in par. IV.6. "Disciplinary, civil, and/or criminal proceedings should be initiated against the perpetrators of abuse of office, and appropriate sanctions should be provided for the established abuse." CEPEJ Guidelines from 2009, no. 80-82 compels countries that have enforcement officers in their legal system to subject enforcement officers who violate the law, regulations, or ethical rules, even outside the performance of their duties, to disciplinary sanctions, which does not exclude possible civil and criminal sanctions. Disciplinary proceedings should take place before an independent body to avoid conflicts of interest and ensure transparency, and "the powers and obligations of the enforcement officer should be clearly defined and delineated concerning the powers and obligations of the judges." by Recommendation no. 17 (2003) par. IV5. The 2009 CEPEJ Guidelines emphasize the importance of establishing a professional organization.

According to the LESI, all public enforcement officers and deputy public enforcement officers are obligatory members of the professional association, the Chamber of Public 
Enforcement Officers. The work of the Chamber is supervised by the ministry, according to the law governing the state administration. The Supervisory Board is one of the bodies of the Chamber that supervises the legality of work and financial operations of the Chamber. The public enforcement officer is disciplinary liable for the violation of the law, other regulations, non-fulfillment of obligations determined by the Statute, other regulations or general acts of the Chamber, or due to violation of the reputation of public enforcement officers (Art 525 LESI). In this regard, is obligated to adopt the Code of Ethics of Public Enforcement Officers and to initiate disciplinary proceedings against public enforcement officers who do not comply with the provisions of the Code, under the law and the statute. In addition to ensuring that public enforcement officers respect the provisions of the Code of Ethics and initiating disciplinary proceedings the Chamber of Public Enforcement Officers also has supervisory powers. At least once in two years, it performs regular supervision, during which it checks the application of the Standard of Professional Conduct of Public Enforcement Officers, and it can also perform extraordinary supervision upon the complaint of a party or participant in the procedure. The Chamber may order the public enforcement officer to eliminate the deficiencies within a certain period if that is possible due to the nature of the matter. The minutes on supervision and evidence are forwarded to the disciplinary prosecutor of the Chamber and the disciplinary prosecutor of the ministry. Based on such supervision, the request for initiating disciplinary proceedings may be submitted by the President of the Chamber of Public Enforcement Officers, as well as upon the complaint and initiative of the parties in the proceedings. The disciplinary prosecutor of the Chamber supervises the work of public enforcement officers in the procedure upon complaints of the parties or participants in the procedure.

From the above, it is clear that the part of the Chamber is great, generally speaking, selfgoverning. It could, in the most general way, be divided into two components: 1) selfgoverning in the narrow sense and 2) supervisory. The role of the Chamber is that the Chamber is obliged, on the one hand, to adopt a Code of Ethics, preserve the reputation, honor, and rights of the profession, represent enforcement officers in front of state bodies to protect the rights and interests of the profession, take care of professional training, meetings, seminars, and consultations in the field of enforcement, establishes and realizes cooperation with chambers of enforcement officers of other countries, etc. (self-governing role in a narrower sense); on the other hand, it supervises ex officio, orders the enforcement officers to eliminate the deficiencies within a certain period and initiates disciplinary proceedings (through its competent authorities). Having in mind that the subject of supervision is the realization of duties or goals determined by law, the Chamber is endowed with powers. Self-governing powers enable the Chamber of Public Enforcement Officers to regulate the profession and take care to achieve all those goals listed in Art. 514 of LESI. 


\section{Ministry of Justice and control mechanisms}

The work of the Chamber is supervised by the ministry, according to the law governing the state administration. The LESI itself does not contain any additional provisions on the procedure, frequency, on whose initiative supervision is performed, etc. The Ministry of Justice supervises the legality of the work of the enforcement officers on its own initiative, at the proposal of the president of the court for whose territorial jurisdiction the public enforcement officer is appointed or on the complaint of another public enforcement officer, party or participant in the procedure. The Ministry of Justice supervises the legality of work of the enforcement officers on its own initiative, at the proposal of the president of the court for whose territorial jurisdiction the public enforcement officer is appointed or on the complaint of another public enforcement officer, party or participant in the procedure. The Ministry is authorized to: 1) obtain, from the parties and participants in the procedure and the presidents of the courts for whose territorial jurisdiction the public enforcement officer is appointed, all data on the manner in which the public enforcement officer made decisions and conclusions and undertook enforcement and security interest actions; 1a) collects and processes data, referred to in Article 503 of LESI, in accordance with the law governing the protection of personal data; 2) request documentation on the amount of costs of the enforcement and security interest procedure; 3 ) requests reports and evidence on how the acts of courts and public enforcement officers and writs for parties and other participants in the procedure were delivered; 4) makes an insight into the choice of means and objects of enforcement and their changes during the enforcement procedure or security interest procedure; 5) requests a report on whether and how many times the same act of enforcement or security interest has been repeated; 6) makes an insight into the work of the office of the public enforcement officer in order to check the application of the Standard of Professional Conduct of Public Enforcement Officers; 7) makes an insight into the records on enforcement and security interest procedures and financial operations; 8) obtains other information necessary to decide whether disciplinary proceedings will be initiated against the public enforcement officer. The civil servant who performed the supervision is obliged to forward the report on the supervision and evidence to the disciplinary prosecutor of the ministry and the disciplinary prosecutor of the Chamber. If we analyze in detail the powers of the Ministry of Justice in terms of supervising the work of public enforcement officers, we can answer the above "question" whether the executive seizes the competence of the judiciary. Unlike the authority of the Ministry of Justice, which is limited when it comes to courts (control of the legality of judges' actions, i.e. whether deadlines are met, whether a judge performs his work conscientiously, etc.), or the prosecutor's office, such a limitation does not exist when it comes to controlling work of public enforcement officers. It seems that the Ministry of Justice, by introducing the possibility of controlling the manner of decision-making of a public enforcement officer in a specific case (e.g. it can control the choice of means and subject of enforcement), has "entered" the jurisdiction that belongs to the courts. The Ministry of Justice should have a central role in the so- 
called administrative supervision, and by no means have a control function, which should certainly belong only to the court. The Ministry should perform regular and extraordinary supervisions (controls) related to e.g. control of fulfillment of working conditions, general criteria, such as name board, seal, working hours, archiving of cases, tidiness of records, etc. and in no way to interfere in the actions and decisions of the public enforcement officers made in a specific case.

If the disciplinary prosecutor of the ministry concludes that disciplinary violations have occurred, he/she submits a request for establishing disciplinary responsibility to the disciplinary commission, which decides upon it after an oral hearing.

\section{Judicial control of public enforcement officers}

Courts are the only bearers of judicial power who exercise decision making. In the exercise of judicial power, and when it comes to the enforcement procedure, one part of the work is performed by other bodies, i.e. individuals. Regarding that, the division of tasks and powers, all bodies must cooperate, share the adopted positions, educate and improve together, all with the aim of better functioning of the entire judicial system, and thus the enforcement procedure.

The public enforcement officer decides on the motion for enforcement based on a writ of execution or credible document to settle a monetary claim arising from communal services and related activities, and on the motion for enforcement to settle a monetary claim against the enforcement debtor from Art.300 LESI. ${ }^{6}$ The public enforcement officer decides on such a submitted motion in the form of a writ of execution against which an objection is allowed, upon which is decided by the appropriate court. If the decision is made based on a motion submitted on an executive document, claim that arises from utility services and related activities, an appeal is allowed, which is decided by the appropriate second instance court. Therefore, when the public enforcement officer is authorized by law to make a writ of execution, the parties in the procedure have the right to object or appeal against such decisions. Judicial control of the legality and regularity of the enforcement officers' actions whilst composing writ of execution, as well as other decisions in which the right to object or appeal is allowed, is obvious and present. The public enforcement officer has jurisdiction for carrying out almost all enforcement's (except those reserved for the court). With the amendments to the LESI has undergone major changes in the provisions of Art. 4 relating to the competence

6 Author's note: By intervening in Art. 3 of the Law, the competence of public enforcement officers is expanded, so that in cases of settling a monetary claim arising from communal services and related activities, the public enforcement officer decides on the writ of execution on the basis of the executive document. In regards with deciding on the enforcement proposal, the enforcement proposal on the basis of an enforcement or credible document in order to settle a monetary claim against the enforcement debtor, under Art. 300 para. 2, 3 and 4 shall be decided by the public enforcement officer. In the opinion of the author, this will enable relieving the courts in enforcement matters, considering that these are a large number of proceedings. 
of enforcement and gave public enforcement officers broader powers. ${ }^{7}$ During the enforcement, most decisions that are made by public enforcement officers are in the form of a conclusion, to which no objection or appeal is allowed. However, to provide some kind of protection, first to the enforcement debtor, the legislator prescribed that the parties or participants in the procedure have the opportunity to submit a request for elimination of irregularities during, and on the occasion of enforcement proceedings, within eight days from the day of the irregularity. The request can be submitted primarily against irregularities committed during the enforcement proceedings - actions performed during and on the occasion of the enforcement, and only exceptionally against the conclusion of the public enforcement officer. While against the writ of execution made by the court or public enforcement officer it can't be submitted. The request is

7 Paragraph 4 in Art. 1 is changed, so that it now reads: "The court is exclusively competent to perform an act that can be undertaken only by the enforcement debtor, inaction or suffering (Art. 363, 364 and 366), return of the employee to work and enforcement of executive documents related to family relations, except for the collection of legal support." The first change in paragraph one refers to the issue of jurisdiction for the joint sale of real estate and movables, which is now in the exclusive jurisdiction of the public enforcement officer, and not the court. Even if such situations were rare in practice, there was no reason why the legislator prescribed that the enforcement of joint sale of real estate and movables be in the exclusive jurisdiction of the court, since public enforcement officers are certainly exclusively competent to carry out execution on both real estate and movable things. Most often, during the enforcement procedure itself, it became known that within the real estate on which the court allowed the enforcement, there were also movables, accompanying installations or equipment that would be suitable for enforcement on them, by joint sale of real estate and those movables, this caused problems in practice. In this phase of enforcement it was impossible to change and substantially comply with the imperative norm of the law on the exclusive jurisdiction of the court. The second change in paragraph one refers to the limitation of the exclusive jurisdiction of the court with regard to the enforcement of an act, so that the restriction refers to acts that can be undertaken only by the enforcement debtor. These are issues from Chapter IV and they imply actions that can be taken only by the enforcement debtor (Art. 363), while other actions are now in the exclusive competence of the public enforcement officer. The third change in paragraph one refers to the enforcement of executive documents related to family relations, where the court is now exclusively competent to enforce all executive documents related to family relations, except when it comes to collecting legal support, which is now in the exclusive jurisdiction of the public enforcement officer. With these changes, the legislator removed the dilemma that existed in practice and now clarified that the term family relations means all family relations except those related to the collection of monetary claims for child support, spousal or kinship support (legal support). However, the division of exclusive jurisdiction of the court and the public enforcement officers in this area, in our opinion, may cause new problems in practice and of a technical nature, given that the content of the operative part of the judgment in family disputes (mostly in divorce cases) is regulated imperative norm of family law (which in the above situations can lead to situation where one enforcement document is enforced by two different bodies. For example, the manner of seeing the child will be carried out by the court, and the collection of legal support will be carried out by the public enforcement. 
submitted to the court or the public enforcement officer, it all depends on who carries out the enforcement, and they are obligated to decide on it within eight days, provided that the request does not delay the enforcement. If the request is founded, the court, i.e. the public enforcement officer shall resolve the issue with a decision and if it is possible to eliminate irregularities, i.e. order the elimination of irregularities committed during and on the occasion of the enforcement. The motion for the elimination of irregularities is decided by a decision, against which an objection is allowed. The court that issued the writ of execution based on an executive or credible document shall decide on the objection made on the decision of the public enforcement officer, by which the request for elimination of irregularities was rejected or adopted. The court will, if possible, first order that the irregularities be eliminated, that is to restore the previous state that existed before an "illegal" action was taken.

It follows from the above that the control role of the court exists during the entire enforcement procedure, for all actions taken by the public enforcement officer, which adequately protects the interest of the participants in the procedure.

\section{Conclusion}

The public enforcement officer is a private judicial profession with entrusted public authority. The public enforcement officer exercises the public powers entrusted to him by the Law on Enforcement and Security Interest or another law. He performs the activity as an entrepreneur or as a member of a partnership whose members are exclusively public enforcement officers. He has a status of an official and conducts the enforcement within the limits of the writ of execution and performs other authorities entrusted to him by the Law on Enforcement and Security Interest and other laws. From all the above, it can be concluded that the state (justifiably) transferred to public enforcement officers' part of its powers, namely those that were within the jurisdiction of the courts. In that way, public enforcement officers became a part of the judicial system. By establishing such a system of enforcement, introducing public enforcement officers, with the tendency to transfer increasing jurisdiction from the courts to public enforcement officers, the Republic of Serbia has finally got an efficient and effective enforcement system. Especially in enforcement proceedings when the object of enforcement is the real estate of the enforcement debtor, amongst all agricultural land, which was difficult to enforce by the courts and even more difficult to complete (by selling the real estate and settling the enforcement creditor from the sale price).

Such a system of enforcement is subject to great control. The control is performed at three levels: by the competent courts, the Chamber, and the Ministry of Justice. There are different opinions on whether established control is adequate. The authors of this paper are of opinion that enhanced control is always welcome, and that public enforcement officers, as a new profession, must be controlled in their work by courts for legal remedies, as well as by the competent bodies of the Chamber and the Ministry of Justice, but that a correction must be made concerning the powers that these bodies have. Interference of the executive in the legislative or judicial power is not abided by the 
Constitution, and the LESI enables exactly that. In practice, it is not so rare that different decisions on the same legal matter or legal issue were made by the competent court and the Ministry of Justice, where the court, for example, took the position that the public enforcement officer did not commit an irregularity in the case, for taking or not taking specific actions, and the Ministry of Justice found an irregularity and imposed some of the disciplinary measures despite the court's decision that there were no irregularities. We consider that it is necessary to pass the Law on Public Enforcement Officers as soon as possible, following the example of other professions (e.g. notaries) and to separate the procedural part, adequately and necessarily, and regulate in more detail all areas and issues concerning public enforcement officers, their work, organization, supervision, and control.

\section{Conflict of interests}

The authors declare no conflict of interest.

\section{References}

1. Andrei, J. V., Mieila, M., \& Panait, M. (2017). The impact and determinants of the energy paradigm on economic growth in European Union. PloS one, 12(3), e0173282. doi: https://doi.org/10.1371/journal.pone.0173282

2. Bodiroga, N. (2015). Judicial control of work of public enforcement officers. Anali pravnog fakulteta u Beogradu, 63(2), 61-77. doi: https://doi.org/10.5937/ AnaliPFB1502061B

3. Bodiroga, N., Ujdehag, J., Ginzburg, S., Popov, K., Bengston, B., \& Milošević, M. (2014). Sveobuhvatna analiza sistema izvršenja u Srbiji, Beograd, 228.

4. Crnjanski, V. (2018). Izvršnost javnobeležničkog zapisa (doktorska disertacija), Pravni fakultet Univerziteta Union, Beograd, Srbija.

5. Đurđević, D. (2014). Javnobeležnička delatnost, Dosije Studio, Beograd, Srbija, 23.

6. Evropski sud za ljudska prava (2008). Bulović protiv Srbije, presuda od 1. aprila 2008, Retrieved from http://www.zastupnik.gov.rs/cr/articles/presude/ (April 3, 2020).

7. Ilić protiv Srbije, ESLjP, presuda od 9. oktobra 2007, predstavka br. 30132/04, Retrieved from http://www.zastupnik.gov.rs/cr/articles/presude/u-odnosu-na-rs/ ilic-protiv-srbije-br.-predstavke-30132-04.html (March 12, 2020).

8. Lazarević, D. (2014). Komentar zakona o izvršenju i obezbeđenju, 3. izmenjeno i dopunjeno izdanje, Poslovni biro, Beograd, Srbija.

9. Milkov, D. (2009). Upravno pravo, Prva uvodna i organizaciona pitanja, Pravni fakultet, Novi Sad, Srbija. 
10. Nikolić, M., Sibinović, D. Đ., Spasić, S., \& Šarkić, N. (2012). Pravo pravosudnih profesija, Pravni fakultet Univerziteta Union, Beograd, Srbija.

11. Pajvančić, M. (2009). Komentar Ustava Republike Srbije, Konrad Adenauer, Beograd, Srbija.

12. Pakić-Vodinelić, V. (2012). Pravosudno organizaciono pravo, dugo izmenjeno $i$ dopunjeno izdanje, Pravni fakultet Univerziteta Union, Beograd, Srbija.

13. Pravilnik o disciplinskom postupku protiv javnih izvršitelja, Službeni glasnik RS, br. 32/16, Retrieved from https://www.pravno-informacioni-sistem.rs/S1GlasnikPortal/ eli/rep/sgrs/ministarstva/pravilnik/2016/32/1/reg (February 11, 2020).

14. Pravilnik o nadzoru nad radom javnih izvršitelja i zamenika javnih izvršitelja, Službeni glasnik RS, br. 63/2018, Retrieved fom https://www.pravno-informacionisistem.rs/SlGlasnikPortal/eli/rep/sgrs/drugeorganizacije/pravilnik/2018/63/1/reg (April 12, 2020).

15. Preduzeće EVT protiv Srbije, presuda od 21. juna 2007, predstavka br. 3102/05, Retrieved from http://www.zastupnik.gov.rs/cr/articles/presude/u-odnosu-na-rs/ preduzece-evt-protiv-srbije-br.-3102-05.html (April 20, 2020).

16. Samardžić i AD Plastima protiv Srbije, presuda od 17. jula 2007, predstvaka br. 28443/05, Retrieved from http://www.zastupnik.gov.rs/cr/articles/presude/uodnosu-na-rs/samardzic-i-ad-plastika-protiv-srbije-br.-28443-05.html (April 23, 2020).

17. Skupština Komore javnih izvršitelja(2016). Etičkikodeks javnih izvršitelja, Službeni glasnik RS, br. 105/2016, Retrieved from https://www.pravno-informacioni-sistem. rs/SlGlasnikPortal/eli/rep/sgrs/drugeorganizacije/kodeks/2016/105/1 (February $23,2020)$.

18. Smernice CEPEJ iz 2009, Retrieved from https://www.coe.int/en/web/cepej/ documentation/cepej-documents/guidelines (April 24, 2020).

19. Smiljanić Ličina, M. (2018). Izvršne isprave koje nastaju u toku izvršnog postupka. Pravni informator, 20(5), 15-27.

20. Šarkić, N. (2016). Kometar Zakona o izvršenju i obezbeđenju, Paragraf Lex, Beograd, Srbija.

21. Šite, D. (2015). Kolege Glembajevi: Zapis o našim prvim privatnim izvršiteljima, Lyceum Iuris, Subotica, Srbija.

22. Tomić, Z. (2016). Opšte upravno pravo, Pravni fakultet u Beogradu, Beograd, Srbija. 
23. Zakon o izvršenju i obezbeđenju, Službeni glasnik RS, br. 106/2015, 106/2016 autentično tumačenje, 113/2017 - autentično tumačenje i 54/2019, Retrieved from https://www.pravnoinformacionisistem.rs/SlGlasnikPortal/eli/rep/sgrs/skupstina/ zakon/2015/106/1/reg (February 12, 2020).

24. Zakon o parničnom postupku, Službeni glasnik RS, br. 72/2011, 49/2013 - odluka US, 74/2013 - odluka US, 55/2014, 87/2018 i 18/2020, Retrieved from https:// www.pravno-informacioni sistem.rs/SlGlasnikPortal/eli/rep/sgrs/skupstina/ zakon/2011/72/2/reg (January 14, 2020).

25. Zakon o poljoprivredi i ruralnom razvoju, Službeni glasnik RS, br. 41/2009, 10/2013 - dr. zakon i 101/2016, Retrieved from https://www.pravno-informacioni-sistem. rs/SlGlasnikPortal/eli/rep/sgrs/skupstina/zakon/2009/41/3/reg (January 21, 2020).

26. Zoroska-Kamilovska, T. (2015). Reforme sistema izvř̌enja u državama regiona - konceptualne sličnosti i rezlike, kontroverze i dileme, Pravni fakultet „Justinijan Prvi“, Skoplje, Severna Makedonija. 